\title{
Behavioural Finance and Investment Decisions: Does Behavioral Bias Matter?
}

\author{
Etse Nkukpornu ${ }^{1}$, Prince Gyimah $^{2}, \&$ Linda Sakyiwaa $^{3}$ \\ ${ }^{1}$ Department of Accounting and Finance, Christian Service University College, Kumasi, Ghana \\ ${ }^{2}$ Department of Accounting Studies Education, University of Education, Winneba, Kumasi-Campus, Ghana \\ ${ }^{3}$ Finance Department, Kumasi Technical University, Kumasi, Ghana \\ Correspondence: Etse Nkukpornu, Department of Accounting and Finance, Christian Service University College, \\ Kumasi, Ghana.
}

Received: September 14, 2020

Accepted: October 13, $2020 \quad$ Online Published: October 21, 2020

doi:10.5539/ibr.v13n11p65

URL: https://doi.org/10.5539/ibr.v13n11p65

\begin{abstract}
This paper examines the nexus between behavioural bias and investment decisions in a developing country context. Specifically, this study tests the effect of four behavioural biases (overconfidence, regret, belief, and "snakebite") on investment decisions. Descriptive statistics and inferential statistics including multiple regression are used to examine the behavioural biases-investment decisions nexus. The study reveals that the four bias have a significant positive and robust relationship with investment decision making. The result also shows that the "snakebite" effect contributes more to the decision making, followed by belief bias then regret bias. Overconfidence bias, however, contributes the least effect on investment decisions. Our contribution confirms the prospect theory and that behavioural bias influences investment decisions in the developing country perspective.
\end{abstract}

Keywords: behavioral Finance, behavioural bias, investment decisions, finance, developing countries

\section{Introduction}

Investors for many years depends on the modern financial theories and expert opinions in making investment decisions to maximize returns either in the short term or long term. Finance theories and models such as Capital Structure (Modigliani \& Miller, 1958); Capital Asset Pricing Model (Sharpe, 1964; Lintner, 1965, and Mossin, 1966); Efficient Market Hypothesis (Fama, 1970); and Options Pricing model (Black and Scholes, 1973) postulated that investors are rational, and they base on available information in making decisions. Chin (2012) suggested that the logical nature of investors in decision making could not explain the volatile nature of the stock market because of some behavioural biases. Thus, the finance theories regarded these as irrelevant. However, the collapse of the deep-rooted institution such as Long Term Capital Management companies (LTCM) due to stock market changes indicates that something was wrong with modern financial theories (Prosad et al., 2015). Nofsinger and Varma (2014) added that these anomalies delineate that something was lacking in the contemporary theory of rationality.

Henceforth, Kengatharan (2014) argued that investors do not behave rationally because cognitive and emotional biases could influence their decisions. Jaiyeoba and Haron (2016) suggested that investors do not follow the strictly complex mathematical theory of prediction when making financial decisions under uncertainties and investors relied on behavioural factors to make investment decisions, especially in the stock markets. Kahneman and Tversky (1979) argued that investment decisions are based on psychological underpinnings, and their argument led to the resurgence of behavioural finance in recent times to complement the modern finance theories (Ahmad et al., 2017; Jaiyeoba \& Haron 2016). Behavioural finance postulates that human beings are irrational in their decision making (Ahmad et al. 2017). Ahmad et al. (2017) further argued that the irrationality nature of human beings is biological, psychological, and sociological. Other Scholars posit that behavioural biases have a significant influence on individual investors than institutional investors who depend on expert portfolio advisors in decision making (Barberis and Thaler, 2003; Fama, 1998).

Surprisingly, existing literature has not fully delved into studying behavioural finance to access its relevancy. The few extant studies on behavioural finance also have fragmented results from diverse contexts (Ahmad et al., 2017; Jaiyeoba \& Haron, 2016; Prosad et al., 2015). For instance, whiles Prosad et al. (2015) argued that behavioural 
biases are contingent on investor's demographics and overconfidence, Jaiyeoba and Haron (2016) stipulated that investment decisions are based on psychological preferences that are context-driven. Also, several studies in developed countries and few emerging markets found that behavioural biases influence investment decisions (Kengatharan, 2014; Qadri \& Shabbir, 2014; Nofsinger \& Varma, 2014; Jaiyeoba \& Haron, 2016; Prosad et al. 2015). This conclusion has not been ascertained in developing countries, especially in the West African countries. This study fills these gaps in research regarding true predictive abilities of the constructs of the behavioural biases or factors that influence investor's decisions. Specifically, the study examines the effects of behavioural biases on investment decisions in a developing country, Ghana.

Our contributions are fivefold. First, the study's results would enable the practitioners to identify their mistakes and provides particularly suitable suggestions for financial experts in making stock investment decisions. This could allow financial advisors to become more prudent in understanding the psychology of their clients and enable them to improve investment portfolios. Second, investment bankers would understand the market feelings as they float shares to make a reasonable financial decision to help maximize their returns. Third, the study addresses the information deficiency to government and seekers of finance from the Stock Exchange and Securities in developing countries on the behavioural biases. This would form the foundation of formulating strategies on how to maximize Stock Exchanges potential as capital seekers. Also, the study's findings would help policymakers to appreciate the implication of future decisions, policies, and regulations. Finally, the study will contribute to, arguably, the available literature in the field of behavioural finance from the developing context perspective. The findings will complement the modern theories in investment decision making not only in the Ghana Stock Exchange (GSE) but also in the stock market in other developing countries.

The rest of the study is structure as follows. Section 2 reviews the relevant theoretical and empirical literature on behavioural finance and investment decisions. Section 3 and Section 4 presents the methods and results, respectively. Chapter 5 concludes the study and offers recommendations for further research.

\section{Literature Review}

\subsection{Theory and Hypothesis}

The theories of behavioural finance include Bounded Rationality Theory, Prospect Theory, Theory of Mind, and Activating - Beliefs - Consequences (ABC). However, this study is backed by Prospect Theory (PT). The PT is an alternative model of decision-making under risk and uncertainty (Kahneman \& Tversky, 2013). PT posits that individual choices are in two phases, namely framing and evaluation. During the framing stage, the individual investor constructs a representation of the acts, contingencies, and outcomes significant to the decision. For the evaluation stage, the individual investor assesses each of the prospects available and makes a decision (Tversky and Kahneman, 2013). The following are the characteristics of the choice value according to the PT: Defined on deviation from the reference point, which indicates concave for gains and convex for losses, steeper for damages than for benefits; and having a nonlinear transformation of the probability scale (Tversky \& Kahneman, 2013). PT describes several states of mind that can be expected to influence an individual's decision-making processes. According to Bashir et al. (2011), many behavioural biases influence investors' decision to buy or sell stocks. This study will focus on the following; Belief bias, Regret bias, Snakebite effect or bias, and Overconfidence bias. These behavioural biases are discussed as follows.

\subsubsection{Belief Bias}

Belief is the investor's ideas that are faithful to him or her or the stability of an investor's state of mind and perception of particular dynamics about the environment (Chin, 2012). Self-confidence as a result of beliefs of the individual means to trust in once self (Tversky \& Kahneman, 1991). An investor with confidence does not depict that predictions about investment decisions may always result in gains. Emotions have an immense impact on investment decision-making and most investors loss money as a result of behavioural factors (Chin, 2012). A positive mood can result in a better and appreciable gain on investment. Investors mostly have challenges in modifying existing ideas when they are confronted with a new set of decisions or contradictory information (Chin, 2012). Therefore, they encounter mental discomfort in having to reconcile based on their belief. The study, therefore, hypothesized that:

\section{Ho: There is no influence of belief bias on individual investment decisions.}

\subsubsection{Regret Bias}

Regret is the phenomenon when an individual investor regrets about the past loss of investment (Chin, 2012; Shefrin, 2002). Regret aversion may results in indecision and failure on the part of the investor to consider an investment due to the fear of the unfavourable outcome. This bias restricts investors to take necessary action due to 
the regret of a previous failure (Chin, 2012; Shefrin, 2002). Regret aversion may be linked with risk aversion since people occasionally may fear not buying the right financial assets or buying the wrong assets. Investors may want to do away with emotional trauma associated with making bad decisions. For example, individuals who suffered losses on their investment might become conservative to minimize the pain associated with additional losses. Regret averse investors may strategically adopt a habit of investing in short- term bonds to mitigate the volatility of the stock market (Chin, 2012). Regret adverse investors may also monitor the price of the stocks already sold and tend to regret if the price changed upwards after the sale. According to Raheja and Dhiman (2017), people anticipate lament if they settle on an off-base decision and will consider this forecast when making choices in the future. Regret bias may primarily make investors feel and concentrate on gains on investment than losses because investors are allergic to missed opportunities. Das and Mohaptra (2017) posited that regret can help people to analyze the situation. Shefrin (2010) asserted that regret bias is an "emotion of pain and anger" which occurs when investors realized that they are involved in a bad investment. Again, Shefrin (2010) concluded that investors have regret when they buy stock and sell it at a price below the purchased price. Hence the study hypothesized that:

\section{Ho: Regret bias does not affect the individual investment decision.}

\subsection{3 "Snakebite" Effect or Bias}

The snakebite effect is the unwillingness of an investor to undertake an investment after making a loss (Chin, 2012; Ghelichi et al., 2016). The behaviour pattern to this effect is different if the repeat behaviour is linked to the reinvestment of earlier stock that resulted in gains (Ghelichi et al., 2016). The "Snakebite" effect is a danger that threatens investors in decision making and is considered as a dominant theory to explain the behaviour of investment decision making in a condition of uncertainty (Kahneman \& Tversky, 2013; Ghelichi et al., 2016). The "snakebite" effect is opposite to the influence of overconfidence. The "snakebite" effect makes investors less confident in making investment decisions (Chin, 2012). The impact of not taking an investment due to an earlier loss may result in the possibility of potential gains from buying the investment at a relatively low price.

According to Barber and Odean (2013), after investors experience a loss on investment, they become unwilling to take risks on their next venture. A study conducted by Das and Mohapatra (2017) strongly evidenced that the "snakebite" effect influence investors in making decisions that may result in errors in their judgement. Another study reviewed that "snakebite" causes the fear to take risks that prevent investors from profit lock which affects investment's returns (Kartasova et al., 2014). Hence the study hypothesized:

\section{Ho: "Snakebite" effect does not affect the individual investment decision.}

\subsubsection{Overconfidence Bias}

Overconfidence bias is an excessive belief in investor's judgements and abilities based on experience and information available to him. Based on the information they are preview to, investors tend to believe that they know more. They found on knowledge and skills and disregarded the risk associated with the investment (Raharja et al., 2017). Overconfidence bias has a significant favourable influence on investment decisions (Subash, 2012). It shows that investors associate higher returns on investment due to previous knowledge and capacity, and blame lower returns on lousy luck (Qadri \& Shabbir, 2014). Overconfidence makes investors too confident about their investment decision. Odean (1999) asserted that overconfidence overestimates the accuracy of knowledge about the value of security. According to Agrawal (2012), overconfidence is among the most essential and useful behavioural biases that have many hostile consequences for investors such as lower expected utility, a higher tendency of leaving the market, excessive transactions, and lower returns on investment. It is evidenced in the literature that overconfidence causes investors to have economic returns on their investment. Additionally, Subrahmanyam (2008) confirm that, in general, overconfidence is harmful to individual investors. For instance, Eichholtz and Yonder (2011) found out that overconfidence in investment decisions negatively affect firm's performance. Odean (1999) also added that individual investors with discount brokerage accounts become overconfident and engage in extra trading that leads to their inability to cover their transaction expenses. Overconfidence always causes investors to underestimate risk and overestimate their knowledge based on the fact that they have more information. Hence the study hypothesized that:

\section{Ho: Overconfidence bias does not influence an individual's investment decision.}

\subsection{Empirical Review}

Lim's (2012) found that overconfidence, conservatism, and regret have a significant favourable influence on investment decisions, but herding behaviour was found not to influence investors' decisions. Kengatharan and Kengatharan (2014) in a similar study found out herding bias, prospect, availability, and market factors have a moderate influence on investment decisions except for anchoring bias that has a high impact on investment 
decisions. According to Ngoc (2014), overconfidence, loss aversion, market factor, and regret have a moderate influence on investment decisions, however, market factors exhibit a more substantial impact on a resolution in investment.

Kafayat (2014) found out that overconfidence, over-optimism, and self-attribution influence decision are negatively correlated with investment decisions. Ramiah et al (2016) found out that overconfidence bias influences investment decisions. Qadri and Shabbir (2014), in their study, found out that overconfidence bias and "illusion of control" have a significant favourable influence on investment decisions. The following biases such as overconfidence, anchoring, regret bias, and loss aversion, influence investment decision making, according to Tripathy (2014).

Wamae (2013), in a study conducted in Kenyan, found out that behavioural factors such as herding bias, prospecting, risk aversion, and anchoring bias influence investment decisions. The study also found out that herding bias is the most significant influence follow by prospecting, anchoring bias, and risk aversion. In a survey conducted by Bashir et al. (2013), the result shows that the overconfidence bias, confirmation bias, the illusion of control, excessive optimism also have a positive and significant influence on investment decisions. Also, preferences such as loss aversion, mental accounting, and status quo, however, exhibited no influence on investment decisions. Other research conducted found out that the "recency effect" has an impact on share repurchasing behaviour (Nofsinger \& Varma, 2014). Babajide and Adetiloye (2012) found out that biases such as overconfidence bias, loss aversion, framing, and status quo have influence investment decisions but weak negative correlation on stock market performance.

According to Qureshi et al. (2012), representative bias, gamblers fallacy, anchoring, overconfidence bias, availability bias, and risk aversion have a significant favourable influence on decision making in Pakistan. The study conducted by Mbaluka et al. (2012) found out that framing and regret influence investment decisions. Luong et al. (2011) found out that overconfidence bias, market factor, availability bias, anchoring, and prospecting have a moderate influence on investment decisions with market factors having the highest effect. The study also found out that three preferences (herding, prospect, and overconfidence) have an impact on investment performance.

\section{Methods}

\subsection{Design and Data}

We employ a descriptive survey design to collect data using quantitative analysis. Data were gathered from the primary source through the use of a questionnaire because previous studies used primary data to answer the research questions (Bakar \& Yi, 2016; Chin, 2012; Prosad et al., 2015; Subash, 2012). The use of surveys is convenient and avoids researcher bias (Bell \& Bryman, 2007; Gyimah \& Boachie, 2018; Gyimah et al., 2019, 2020). The questionnaire used for the study is adapted and modified from Chin (2012) and Prosad et al. (2015). Data for this research work is collected from the appropriate sector of the population, including professionals and nonprofessionals who have an investment in stocks in the West Africa region, Ghana. Since there is no official list of individual investors in Ghana, the study uses a purposive sampling technique to select a sample of 150 respondents (Sarpong-Danquah et al., 2018). Kent (2007) argues that a sample size of 100 respondents and above is acceptable in quantitative studies. However, out of the 150 samples, only 120 responses were complete representing a valid response rate of $80 \%$.

\subsection{Analysis and Model}

Descriptive statistics including frequency tables, percentages, measures of central tendency, and dispersion (mean and standard deviations) are used to analyze the data. The test statistic for the hypothesis testing is the Pearson correlation coefficient ( $r$ ) that measures the nature and strength of the relationship between variables. Multiple linear regression is also run to show the relationship between the independent variables and a dependent variable. The econometric model for the study is presented below.

Decision making $=\alpha+\beta_{1}$ Belief bias $+\beta_{2}$ Regret bias $+\beta_{3}$ "Snakebite" effect $+\beta_{4}$ Overconfidence bias $+\varepsilon$

Where,

Decision making is measured in terms of the degree of risk the investor is willing to take. The study adopts the decision-making variable "I take the safe option if there is one" by Chin (2012) using a 5-point Likert scale from 1-strongly disagree to 5-strongly agree.

Belief bias variable "I trust the research and past performance of the firm" is adapted from Chin (2012) and Prosad et al. (2015) using a 5-point Likert scale from 1-strongly disagree to 5-strongly agree. 
Regret bias variable "I should hold the stock longer because now the price has increased over the selling price" is adapted from Chin (2012) and Prosad et al. (2015) using a 5-point Likert scale from 1-strongly disagree to 5 -strongly agree.

"Snakebite" effect variable "I worry about the influence of financial crises" is adapted from Chin (2012) using a 5 -point Likert scale from 1-strongly disagree to 5-strongly agree.

Overconfidence bias variable "I can predict the future stock price movement after I did some analysis" is adapted from Chin (2012), Prosad et al. (2015) and Subash (2012) using a 5-point Likert scale from 1-strongly disagree to 5 -strongly agree.

$\alpha$ is the constant

$\beta 1, \beta 2, \beta 3$, and $\beta 4$ are the predictors or coefficient of determination.

$\varepsilon$ - Is the random variable or stochastic term or the error term.

\subsection{Reliability Test}

Cronbach's Alpha is used to test the reliability of the study's variable. Put differently, Chronbach's Alpha affirms the reliability test for the constructs used to examine the influence of Behavioral bias on investment decisions. We record Cronbach's Alpha of $0.651,0.626,0.645$, and 0.651 for belief bias, regret bias, snakebite effect, and overconfidence bias, respectively. All the scales in the instrument shows good reliability because they meet the threshold suggested by Nunally and Bernstein (1994) that argue that Cronbach's Alpha greater than 0.6 is acceptable.

Table 1. Demographics Statistics $(\mathrm{N}=120)$

\begin{tabular}{|c|c|c|c|c|}
\hline & Frequency & Percent & $\begin{array}{c}\text { Valid } \\
\text { Percent }\end{array}$ & Cumulative Percent \\
\hline \multicolumn{5}{|l|}{ Gender } \\
\hline Male & 71 & 59.2 & 59.2 & 59.2 \\
\hline Female & 49 & 40.8 & 40.8 & 100.0 \\
\hline \multicolumn{5}{|l|}{ Age } \\
\hline $18-24$ years & 2 & 1.7 & 1.7 & 1.7 \\
\hline 25 - 30 years & 11 & 9.2 & 9.2 & 10.8 \\
\hline 31 - 40 years & 48 & 40.0 & 40.0 & 50.8 \\
\hline 41- 50 years & 44 & 36.7 & 36.7 & 87.5 \\
\hline Above 50 years & 15 & 12.5 & 12.5 & 100.0 \\
\hline \multicolumn{5}{|l|}{ Education } \\
\hline Diploma & 7 & 5.8 & 5.8 & 5.8 \\
\hline Undergraduate & 44 & 36.7 & 36.7 & 42.5 \\
\hline Postgraduate & 59 & 49.2 & 49.2 & 91.7 \\
\hline $\mathrm{PhD}$ & 10 & 8.3 & 8.3 & 100.0 \\
\hline \multicolumn{5}{|l|}{ Profession } \\
\hline Public Sector (excluding bank) & 49 & 40.8 & 40.8 & 40.8 \\
\hline Private Sector & 3 & 2.5 & 2.5 & 43.3 \\
\hline Bank (including private and public) & 25 & 20.8 & 20.8 & 64.2 \\
\hline Financial Expert & 38 & 31.7 & 31.7 & 95.8 \\
\hline Self-Employed & 5 & 4.2 & 4.2 & 100.0 \\
\hline \multicolumn{5}{|l|}{ Income } \\
\hline Between Ghc501 - Ghc1000 & 3 & 2.5 & 2.5 & 2.5 \\
\hline Between Ghc1001 - Ghc2000 & 61 & 50.8 & 50.8 & 53.3 \\
\hline Above Ghc 2000 & 56 & 46.7 & 46.7 & 100.0 \\
\hline
\end{tabular}

\section{Results}

\subsection{Demographic Statistics}

Table 1 presents the statistics for the demographics variables. In terms of gender, 71 of 120 respondents representing 59.2\% are males while 49 representing $40.80 \%$ are females. The implication is that males have a higher chance to buy and sell shares than females because males take risky investments than females. For the age groups of the sample, 48 representing $40.0 \%$ belong to the age group 31-40 years. The age range of 41- 50 years obtains a frequency of 44 representing $36.7 \%$ whereas 11 respondents representing $9.2 \%$ belonging to the age group 25-30 years. Meanwhile, about 15 respondents representing $12.5 \%$ belong to those above 50 years, two respondents indicating $1.7 \%$ are between the age of $18-24$ years old. The results show that investors in the 
age group of 31-40 years old are most active in stock investment.

On the part of the educational qualification of individual investors, most of the respondents (59) representing 49.2\% have a postgraduate certificate, followed by 44 respondents representing $36.7 \%$ that have an undergraduate certificate. Meanwhile, 10 respondents indicating $8.3 \%$ are $\mathrm{Ph} . \mathrm{D}$. certificate holders, and 7 respondents representing $5.8 \%$ are diploma certificate holders. The results show that most of the investors, about 94.2\% are highly educated (undergraduate, postgraduate, and Ph.D.), and this enhances their skills and knowledge in investing in stocks.

For the profession of investors, 49 respondents representing $40.8 \%$ are in the public sector (excluding banks) followed by financial experts with 38 respondents representing 31.7\%. The rest of the respondents are 25 (20.8\%), 5 (4.2\%), 3 (2.5\%) represent employees of banks (including private and public sector), self-employed, and private sector, respectively. This shows that public sector employees are the most investors that invest in stock in Ghana (Sakyiwaa et al., 2020).

Finally, most of the respondents, 61 representing 50.8\%, are within the income range of GHC 1001-2000. They are followed by those above GHC 2000 with 56 respondents representing $46.7 \%$ and three respondents constituting $2.5 \%$ belonging to the income range between GHC 5001-1000. These results show that those with income range from GHC 1000-2000 are interested in investment to maximize their wealth.

Table 2. Knowledge about Investment $(\mathrm{N}=120)$

\begin{tabular}{|c|c|c|c|c|}
\hline Constructs & Frequency & Percent & $\begin{array}{c}\text { Valid } \\
\text { Percent }\end{array}$ & $\begin{array}{c}\text { Cumulative } \\
\text { Percent }\end{array}$ \\
\hline \multicolumn{5}{|c|}{ How many years you have been investing } \\
\hline Between $1-5$ years & 79 & 65.8 & 65.8 & 65.8 \\
\hline Between $6-10$ years & 41 & 34.2 & 34.2 & 100.0 \\
\hline \multicolumn{5}{|c|}{ How often have you invested in the stock } \\
\hline Below 5 times & 58 & 48.3 & 48.3 & 48.3 \\
\hline Between 5 - 10 times & 45 & 37.5 & 37.5 & 85.8 \\
\hline Over 10 times & 17 & 14.2 & 14.2 & 100.0 \\
\hline \multicolumn{5}{|l|}{ Before making investment } \\
\hline Mostly about potential gains & 70 & 58.3 & 58.3 & 58.3 \\
\hline A little about potential loss & 13 & 10.8 & 10.8 & 69.2 \\
\hline Security of investment & 37 & 30.8 & 30.8 & 100.0 \\
\hline \multicolumn{5}{|l|}{ The decline in value of stock } \\
\hline Ignore & 59 & 49.2 & 49.2 & 49.2 \\
\hline Buy & 1 & .8 & .8 & 50.0 \\
\hline Avoid & 57 & 47.5 & 47.5 & 97.5 \\
\hline Discuss & 3 & 2.5 & 2.5 & 100.0 \\
\hline \multicolumn{5}{|l|}{ Price of investment jumps } \\
\hline More & 5 & 4.2 & 4.2 & 4.2 \\
\hline Lock-in & 52 & 43.3 & 43.3 & 47.5 \\
\hline Stay-put & 63 & 52.5 & 52.5 & 100.0 \\
\hline
\end{tabular}

\subsection{Knowledge about Investment in Stocks}

Table 2 presents the statistics results on how knowledgeable the respondents are in terms of stock investment. Firstly, we asked the respondents how many years they have invested in stocks. The result shows that most of the respondents, 78 representing $65.0 \%$ have been trading stocks between 1 - 5 years. This is followed by 41 respondents representing $34.2 \%$ that have been trading in commodities between 6-10 years, and only 1 respondent representing $0.8 \%$ have been trading in stocks above 10 years. The result shows that most of the investors understand the stock trade and this accounted for 1-5 years in business. They concentrate on other investment portfolios than investment in stocks.

Secondly, we also asked the respondents how often have they have invested in stocks that seem safer to invest. The result in Table 2 shows that 58 of the respondents representing $48.3 \%$ have been trading in commodities below 5 times, and 45 respondents representing 37.5\% have been trading in stocks between 5-10 times. Lastly, 17 respondents representing $14.2 \%$ have been trading in stocks above 10 times. The result shows that investors have stocks, but most of them do not buy their stock because most of them do not know about how to trade their stocks through stockbrokers due to the least number of times of trade below 5 times. We also asked the respondents what they think before investing. Most of the respondents (70 representing 58.3\%) report that they are concern about potential gains. The second most crucial issue is the security of the venture, and about 37 respondents representing 
$30.8 \%$ are in this category, 13 respondents indicating $10.8 \%$ think about little loss. This result shows that investment in stocks is male-dominated and that they are concern about potential gain than others that accounted for the highest response of $58 \%$.

Moreover, when respondents were asked how they will respond when the value of their stock decline $20 \%$, Most of the respondents 70 representing $58.3 \%$ responded to the question, "I would remain invested and ignore temporary changes as I look for long growth". The result indicated most of the respondents are interested in the long-term growth of their investment. The next group of respondents 57, representing $47.5 \%$ responded to the question, "I would sell to avoid further worries and try something else". Lastly, when the respondents were asked how they will respond when the value of their stock jumps by $25 \%$, most of the respondents 63 representing $52.5 \%$ responded to the question "I will stay put and hope for more gain". This shows that the respondents are interested in future gains. The next group of respondents 52 , representing $43.3 \%$ responded to the question "I would sell it and lock in my gains. The remaining of the respondent obtain 5 , representing $4.2 \%$ responded to the question "I would buy more as the price could go higher".

\subsection{Descriptive and Inferential Analysis}

\subsubsection{Descriptive Statistics}

Table 3 provides the detailed test results used to analyze and abridge the questions designed that are based on dependent and independent variables. For the belief bias, the variable "I trust the research and past performance of the firm" obtains the most important mean of 4.62 with a standard deviation of 0.568 . This result shows that individual investors solve problems through pure judgments. As suggested by Tversky and Kahneman (1991), these judgments heuristics help but leads to errors. Chin (2012) posits that investors also spot trends in stock prices, and they expect that the past amount should continue based on their identified pattern.

In terms of regret bias, the item "I should hold the stock longer because now the price has increased over the selling price" recorded a higher mean of 4.78 and a standard deviation of 0.418 . The study is evidenced by Shefrin (2002) and Chin (2012). From Table 3, the item "I worry about the influence of financial crises" in the snakebite effect variable recorded the highest mean of 4.86 with a standard deviation of 0.350 . The analysis indicates most of the respondents fear the financial crisis because they lose a lot of money in stocks as a result of that. The findings confirm the common "adage once biting twice shy". This evidence of the "snakebite effect" is consistent with the works of Chin (2012) and Keller and Pastusiak (2016).

Furthermore, the result in Table 3 shows that most of the respondents are overconfident when it comes to their prediction. The statement in overconfidence bias "I can predict the future stock price movement after I did some analysis" recorded a higher mean of 4.83 with a standard deviation of 0.440 . This findings is consistent with Chin (2012) and Muradoglu and Harvey (2012) and also on a study conducted by Barberis and Thalar (2003) on the topic "self-attribution bias".

Lastly, the decision-making variable (dependent variable) "I take the safe option if there is one" recorded a higher mean of 4.82, a standard deviation of 0.382 . The implication is that most respondents are risk-averse and would select safer options in their decision making. The findings are consistent with Oslen (1998).

\subsubsection{Pearson Correlation Test}

From Table 3, the correlation result indicates that there is a significant positive and robust relationship between belief bias and investment decision, $\mathrm{r}=0.952, \mathrm{n}=120$, and at 0.01 significance level. The implication is that investors believe in the information or news they obtain from other sources. These investors persist in their beliefs based on "hot" tips from some forum and may lead to an overreaction that may result in wrong decision making. The result also indicates that there is a strong significant and positive relationship among regret bias and investment decision, $\mathrm{r}=0.964, \mathrm{n}=120$ at 0.01 significance level. Naturally, it is rational and reasonable that every person will experience regret sometime in life. This finding is evidenced by Shefrin (2009) that finds similar results indicating that investors have regret when they buy stocks and sell them at a price below the purchased amount.

Also, the "snakebite" effect has a positive significant relationship between investment decision $(r=0.946, n=$ $120, \mathrm{p}=0.000$ ). The implication is that investors are prone to fear after a huge loss in the stock market due to financial crises. Investors feel pessimistic and do not have the zeal to buy "winning" stocks. These investors do not want to take a higher risk, and they sell their stocks quickly when they suspect lower prices to avoid further losses. Lastly, the correlation result of $\mathrm{r}=0.867$, $\mathrm{p}$-value $=0.000$, and $\mathrm{n}=120$, indicates that there is significant, positive relationships between overconfidence bias and investment decision. The result also implies that some respondents lack confidence and are pessimistic that their stock prices may fall. 
Table 3. Descriptive and Correlations

\begin{tabular}{|c|c|c|c|c|c|c|c|}
\hline Variables & Mean & $\begin{array}{c}\text { Standard } \\
\text { Deviation }\end{array}$ & 1 & 2 & 3 & 4 & 5 \\
\hline 1. Decision making & 4.82 & 0.382 & 1.000 & & & & \\
\hline 2. Belief bias & 4.62 & 0.568 & $0.952 * *$ & 1.000 & & & \\
\hline 3. Regret bias & 4.78 & 0.418 & $0.964 * *$ & $0.421 *$ & 1.000 & & \\
\hline 4. "Snakebite" effect & 4.86 & 0.350 & $0.946 * *$ & $0.403^{*}$ & $0.440^{*}$ & 1.000 & \\
\hline 5. Overconfidence bias & 4.83 & 0.440 & $0.946 * *$ & $0.436 * *$ & $0.423^{*}$ & $0.411 *$ & 1.000 \\
\hline
\end{tabular}

Significance level: $* \quad$ p-value $<0.05$

$* *$ p-value $<0.01$

Table 4. Regression Test Results

\begin{tabular}{|c|c|c|c|c|c|}
\hline $\begin{array}{l}\text { Model Parameter Estimates } \\
\text { Variables Name }\end{array}$ & & $\begin{array}{c}\text { Model } \\
\beta\end{array}$ & Standard Error & t-Statistics & $\begin{array}{l}\text { Model } \\
\text { Sig. }\end{array}$ \\
\hline _Constant & & 0.083 & 0.013 & 6.330 & 0.000 \\
\hline$\overline{\text { Belief bias }}$ & & 0.276 & 0.009 & 32.391 & 0.000 \\
\hline Regret bias & & 0.264 & 0.011 & 24.477 & 0.000 \\
\hline "Snakebite" effect & & 0.339 & 0.012 & 28.426 & 0.000 \\
\hline Overconfidence & & 0.090 & 0.010 & 8.872 & 0.000 \\
\hline \multicolumn{6}{|l|}{ Model Test Results } \\
\hline $\mathrm{N}$ & 120 & & & & \\
\hline R Square & 0.998 & & & & \\
\hline Adjusted R Square & 0.997 & & & & \\
\hline Model Significance & 0.000 & & & & \\
\hline
\end{tabular}

\subsection{Regression Results}

Table 4 presents the regression results used to examines the bahavioural finance - investment decisions nexus. From the regression analysis in Table 4, the four independent variables explained $99.7 \%$ of the investment decision shown by the adjusted R-squared. The implication is that the four bias contribute $99.7 \%$ to decision in investing in stocks, other variables which are not considered in this study accounted for $0.3 \%$ of investment decision. Put differently, 99.7\% variation in investment decisions of individual investors is explained by behavioural biases. Also, the t-statistic values are greater than 2 with a significant $\mathrm{p}$-value of less than $1 \%$. Thus, the study rejected all the null hypotheses and concluded that all four biases influence investor's decisions.

Holding other factors constant, a unit increase in belief bias resulted in a 0.276 success in the decision in investment. A unit increase in regret bias resulted in a 0.264 outcome in the investment decision. A unit increase in the "snakebite" effect resulted in a 0.339 increase in investment decision making. For overconfidence bias, a unit increase resulted in a 0.090 increase in investment decision making. The result implies that the "snakebite" effect has a high effect on investment decisions, followed by belief bias, regret bias, and overconfidence.

The study again shows that the belief bias has a positive effect on investment decision making. The result is consistent with the study of Coutts (2019), Chin (2012), and Waweru et al. (2008). The study also records a positive significant relationship between regret bias and investment decisions. This confirms the findings of Chin (2012) and Waweru et al. (2008) that recorded similar outcomes. This reaffirms that investors refuse to undertake an investment because of the fear that they may lose it. The study also confirms that investment decision making is strongly influenced by the "Snakebite effect", and agrees with Chin (2012) and Kartasova et al. (2014) study's findings. With overconfidence bias, investors attribute success to talent and expertise, while blaming 'bad luck' for failure. From Table 4, investment decision making is also positively influenced by overconfidence bias. These results are consistent with the studies conducted by Qadri and Shabbir (2014), Lim (2012), Qureshi et al. (2012), Shah et al. (2019), and Bashir et al. (2013) that report that overconfidence has a significant positive impact on investor's decision making. Meanwhile, the findings are inconsistent with Kafayat (2014), and Kengatharan and Kengatharan (2014) that found that overconfidence does not influence decision making.

\section{Concluding Remarks}

This study examines the influence of behavioural biases on individual investment decisions in a developing country context. The research established that the presence of behavioural biases plays a vital role in influencing stock investment decisions. The study finds the four preferences or biases (overconfidence, regret, belief, and "snakebite") have a significant positive and robust relationship with investment decision making in varying 
degrees. The descriptive statistics conclude that individual investors in the West Africa region (Ghana) are young, highly educated, and well experienced in making an investment decision. The study records a significant positive relationship between belief bias and the investor's decision making and implies that investors depend on belief in making decisions such as "hot" tips. Further, people buy stocks because they believe in the recommendations given by others they barely know and opinions from newspapers. Besides, investors follow the crowd to buy or sell the available stock.

Moreover, the study records a significant positive relationship between regret bias and the investor's decision making. In real-life situations, every person experiences regret. Investors must recall to mind events and actions that caused regret to avoid repeating similar mistakes. As they make better decisions, they will not regret it because it is often said that "experience is the best teacher". The study again reports a significant positive relationship between the "snakebite" effect and investor's decision making. When you have a snake bite, and you see the earthworm, you are even more careful and afraid. For this reason, some of the investors who had the experience of bad investment and recorded losses are more reluctant to take a risk to buy shares even though it is appropriate to buy at that particular time. The implication is that they may miss the better opportunity of making higher returns on their investment. Lastly, the result of the study also indicates a significant positive and robust association between overconfidence bias and decision making in investment. The implication is that most of the respondents have self-confidence in their skills, knowledge in their predictions, and they are optimistic when making decisions. The findings of the study are consistent with the literature.

The study's finding is useful to individual investors in identifying their own behavioural biases to understand the dynamics involved in stock trading to enable them to make sound investment decisions-information asymmetry as one of the contributors to investor's indifference. As a result of using heuristics in investment decision making, investment information about stocks should be made available by the Ghana Stock Exchange in a form that would be understood by individual investors to help them make sound investment decisions. Investors are also supposed to be open-minded while making investment and desist from holding on to the previous happenings instead must realize that investment in stocks is dynamic. Individual or retail investors should consider many other variables in their environment rather than focusing on just one in making decisions. Investors should learn how to interpret the market and other economic indicators of the various firms in the stock market because they also affect the performance of their stock.

The study has some limitations that need to be addressed in future studies. There are many behavioural biases documented in the literature, but this study is limited to only four of the preferences. The study recommends that future research should consider the influence of other behavioural biases that are not captured. Also, future studies should view a larger sample across developing countries to confirm the study's findings. Future studies should also consider other economic factors that may affect the decision making of investors apart from behavioural biases. The final word on behavioural finance and investment decisions is not yet said, and more research is welcomed.

\section{References}

Agrawal, K. (2012). A conceptual framework of behavioral biases in finance. IUP Journal of Behavioral Finance, 9(1), 7-18.

Ahmad, Z., Ahmad, Z., Ibrahim, H., Ibrahim, H., Tuyon, J., \& Tuyon, J. (2017). Institutional investor behavioral biases: syntheses of theory and evidence. Management Research Review, 40(5), 578-603. https://doi.org/10.1108/MRR-04-2016-0091

Babajide, A. A., \& Adetiloye, K. A. (2012). Investors' behavioural biases and the security market: An empirical study of the Nigerian security market. Accounting and Finance Research, 1(1), 219-229. https://doi.org/10.5430/afr.v1n1p219

Bakar, S., \& Yi, A. N. C. (2016). The impact of psychological factors on investors' decision making in Malaysian stock market: a case of Klang Valley and Pahang. Procedia Economics and Finance, 35, 319-328. https://doi.org/10.1016/S2212-5671(16)00040-X

Barber, B. M., \& Odean, T. (2013). The behavior of individual investors. In Handbook of the Economics of Finance, 2, 1533-1570. https://doi.org/10.1016/B978-0-44-459406-8.00022-6

Barberis, N., \& Thaler, R. (2003). A survey of behavioral finance. Handbook of the Economics of Finance, 1, 1053-1128. https://doi.org/10.1016/S1574-0102(03)01027-6

Bashir, T., Rasheed, S., Raftar, S., Fatima, S., \& Maqsood, S. (2013). Impact of behavioral biases on investor decision making: Male vs female. Journal of Business and Management, 10(3), 60-68. https://doi.org/10.9790/487X-1036068 
Bell, E., \& Bryman, A. (2007). The ethics of management research: an exploratory content analysis. British Journal of Management, 18(1), 63-77. https://doi.org/10.1111/j.1467-8551.2006.00487.x

Black, F., \& Scholes, M. (1973). The pricing of options and corporate liabilities. Journal of Political Economy, 81(3), 637-654. https://doi.org/10.1086/260062

Chin, A. L. L. (2012). Psychological biases and investor behaviour: Survey evidence from Malaysian stock market. International Journal of Social Science, Economics and Arts, 2(2), 67-73.

Coutts, A. (2019). Testing models of belief bias: An experiment. Games and Economic Behavior, 113, 549-565. https://doi.org/10.1016/j.geb.2018.11.001

Das, U., \& Mohapatra, S. R. (2017). Behavioural Biases in Investment Decision Making: A research study on snakebite and house money effects on Indian Individuals. Asian Journal of Management, 8(3), 460-470. https://doi.org/10.5958/2321-5763.2017.00074.9

Eichholtz, P., \& Yönder, E. (2011). CEO Overconfidence, Corporate Investment Activity, and Performance: Evidence from REITs. In The 2011 Annual Meeting of the Academy of Behavioral Finance and Economics, 128.

Fama, E. F. (1970). Efficient capital markets: A review of theory and empirical work. The journal of Finance, 25(2), 383-417. https://doi.org/10.2307/2325486

Fama, E. F. (1998). Market efficiency, long-term returns, and behavioral finance. Journal of financial economics, 49(3), 283-306. https://doi.org/10.1016/S0304-405X(98)00026-9

Feng, L., \& Seasholes, M. S. (2005). Do investor sophistication and trading experience eliminate behavioral biases in financial markets? Review of Finance, 9(3), 305-351. https://doi.org/10.1007/s10679-005-2262-0

Ghelichi, M. A., Nakhjavan, B., \& Gharehdaghi, M. (2016). Impact of Psychological Factors On Investment Decision Making In Stock Exchange Market. Asian Journal of Management Sciences and Education 5(3), 36-44.

Gyimah, P., \& Boachie, W. K. (2018). Effect of microfinance products on small business growth: emerging economy perspective. Journal of Entrepreneurship and Business Innovation, 5(1), 59-71. https://doi.org/10.5296/jebi.v5i1.12378

Gyimah, P., Appiah, K. O., \& Lussier, R. N. (2020). Success versus failure prediction model for small businesses in Ghana. Journal of African Business, 21(2), 215-234. https://doi.org/10.1080/15228916.2019.1625017

Gyimah, P., Marom, S., \& Lussier, R. N. (2019). Small Business Success or Failure Prediction: A Comparative Study in Ghana and Israel. Journal of Applied Business and Economics, 21(3), 37-52. https://doi.org/10.33423/jabe.v21i3.2079

Jaiyeoba, H. B., \& Haron, R. (2016). A qualitative inquiry into the investment decision behaviour of the Malaysian stock market investors. Qualitative Research in Financial Markets, 8(3), 246-267. https://doi.org/10.1108/QRFM-07-2015-0027

Kafayat, A. (2014). Interrelationship of biases: effect investment decisions ultimately. Theoretical and Applied Economics, 21(6), 85-110.

Kahneman, D. (1979). Prospect theory: An analysis of decisions under risk. Econometrica, 47, 313-327. https://doi.org/10.2307/1914185

Kahneman, D., \& Tversky, A. (1982). The psychology of preferences. Scientific American, 246(1), 160-173. https://doi.org/10.1038/scientificamerican0182-160

Kahneman, D., \& Tversky, A. (2013). Prospect theory: An analysis of decision under risk. In handbook of the fundamentals of financial decision making: Part I, 99-127. https://doi.org/10.1142/9789814417358_0006

Kartasova, J., Gaspareniene, L., \& Remeikiene, R. (2014). Influence of "Snake-Bite" Effect on Investment Return Rate: Lithuanian Example. Mediterranean Journal of Social Sciences, 5(27), 1769-1769. https://doi.org/10.5901/mjss.2014.v5n27p1769

Keller, J., \& Pastusiak, R. (2016). The Psychology of Investing: Stock market recommendations and their impact on investors' decisions (the example of the Polish stock market). Acta Oeconomica, 66(3), 419-437. https://doi.org/10.1556/032.2016.66.3.3

Kengatharan, L., \& Kengatharan, N. (2014). The influence of behavioral factors in making investment decisions and performance: Study on investors of Colombo Stock Exchange, Sri Lanka. Asian Journal of Finance and 
Accounting, 6(1), 1-23. https://doi.org/10.5296/ajfa.v6i1.4893

Kent, R. (2007). Marketing research: approaches, methods and applications in Europe. London: Thomson Learning.

Lim, L. C. (2012). The relationship between psychological biases and the decision making of investor in Malaysian share market. In Unpublished Paper International Conference on Management, Economics and Finance 2012 Proceeding.

Lintner, J. (1965). The valuation of risk assets and the selection of risky investments in stock portfolios and capital budgets. The Review of Economics and Statistics, 13-37. https://doi.org/10.2307/1924119

Luong, L. P., \& Ha, T. T. D. (2011). Behavioral factors influencing individual investor's decision making and performance: a survey of the Ho Chi Minh Stock Exchange. Umea School of Business Spring semester. Retrieved from https://www.diva-portal.org/smash/record.jsf?pid=diva2\%3A423263\&dswid=453

Mbaluka, P., Muthama, C., \& Kalunda, E. (2012). Prospect Theory: Test on Framing and Loss Aversion Effects on Investors Decision-Making Process At the Nairobi Securities Exchange, Kenya. Retrieved from http://41.89.227.156:8080/xmlui/handle/123456789/127

Modigliani, F., \& Miller, M. H. (1958). The cost of capital, corporation finance and the theory of investment. The American economic review, 48(3), 261-297.

Mossin, J. (1966). Equilibrium in a capital asset market. Econometrica: Journal of the Econometric Society, 768-783. https://doi.org/10.2307/1910098

Muradoglu, G., \& Harvey, N. (2012). Behavioural finance: the role of psychological factors in financial decisions. Review of Behavioural Finance, 4(2), 68-80. https://doi.org/10.1108/19405971211284862

Ngoc, L. T. B. (2014). Behavior pattern of individual investors in stock market. International Journal of Business and Management, 9(1), 1-16. https://doi.org/10.5539/ijbm.v9n1p1

Nofsinger, J., \& Varma, A. (2014). Socially responsible funds and market crises. Journal of Banking and Finance, 48, 180-193. https://doi.org/10.1016/j.jbankfin.2013.12.016

Nunally, J., \& Bernstein, L. (1994). Psychometric Theory. New York: MacGrow-Hill Higher.

Nunnally, J. C., \& Bernstein, I. H. (1994). Validity. Psychometric Theory, 99-132.

Odean, T. (1999). Do investors trade too much? American economic review, 89(5), 1279-1298. https://doi.org/10.1257/aer.89.5.1279

Olsen, R. A. (1998). Behavioral finance and its implications for stock-price volatility. Financial Analysts Journal, 54(2), 10-18. https://doi.org/10.2469/faj.v54.n2.2161

Prosad, J. M., Kapoor, S., \& Sengupta, J. (2015). Behavioral biases of Indian investors: a survey of Delhi-NCR region. Qualitative Research in Financial Markets, 7(3), 230-263. https://doi.org/10.1108/QRFM-04-2014-0012

Qadri, S. U., \& Shabbir, M. (2014). An Empirical Study of Overconfidence and Illusion of Control Biases, Impact on Investor's Decision Making: An Evidence from ISE. European Journal of Business and Management, 6(14), 38-44.

Qureshi, S. A., \& Hunjra, A. I. (2012). Factors affecting investment decision making of equity fund managers. Wulfenia Journal, 19(10), 280-291.

Raharja, B., Suhaeli, D., \& Mranani, M. (2017). Research of the stock price overreaction and investor overconfidence issues. Business, Management and Education, 15(1), 127-139. https://doi.org/10.3846/bme.2017.358

Raheja, S., \& Dhiman, B. (2017). Influence of personality traits and behavioral biases on investment decision of investors. Asian Journal of Management, 8(3), 819-826. https://doi.org/10.5958/2321-5763.2017.00129.9

Ramiah, V., Zhao, Y., Moosa, I., \& Graham, M. (2016). A behavioural finance approach to working capital management. The European Journal of Finance, 22(8-9), 662-687.

https://doi.org/10.1080/1351847X.2014.883549

Sakyiwaa, L., Gyimah, P., \& Nkukpornu, E. (2020). Preferred investment vehicles of salaried workers of universities in Sub-Saharan Africa. EuroMed Journal of Management, forthcoming.

Sarpong-Danquah, B., Gyimah, P., Poku, K., \& Osei-Poku, B. (2018). Financial literacy assessment on tertiary 
students in Sub-Saharan Africa: A Ghanaian perspective. International Journal of Accounting and Financial Reporting, 8(2), 76-91. https://doi.org/10.5296/ijafr.v8i2.12928

Shah, S. Z. A., \& Ahmad, M. (2019). Entrepreneurial orientation and performance of small and medium-sized enterprises. Competitiveness Review: An International Business Journal, 29(5), 551-572. https://doi.org/10.1108/CR-06-2018-0038

Sharpe, W. F. (1964). Capital asset prices: A theory of market equilibrium under conditions of risk. The Journal of Finance, 19(3), 425-442. https://doi.org/10.1111/j.1540-6261.1964.tb02865.x

Shefrin, H. (2002). Beyond greed and fear: Understanding behavioral finance and the psychology of investing. Oxford University Press on Demand. https://doi.org/10.1093/0195161211.001.0001

Shefrin, H. (2010). Behavioralizing finance. Foundations and Trends in Finance, 4(1-2), 1-184. https://doi.org/10.1561/0500000030

Subash, R. (2012). Role of behavioral finance in portfolio investment decisions: Evidence from India. Retrieved from https://dodo.is.cuni.cz/handle/20.500.11956/43150?locale-attribute=en

Subrahmanyam, A. (2008). Behavioural finance: A review and synthesis. European Financial Management, $14(1), 12-29$.

Tripathy, C. K. (2014). Role of Psychological Biases in the Cognitive Decision Making Process of Individual Investors. Orissa Journal of Commerce, 34(1), 69-80.

Tversky, A., \& Kahneman, D. (1991). Loss aversion in riskless choice: A reference-dependent model. The Quarterly Journal of Economics, 106(4), 1039-1061. https://doi.org/10.2307/2937956

Wamae, J. N. (2013). Behavioural factors influencing investment decision in stock market: A survey of investment banks in Kenya. International Journal of Social Sciences and Entrepreneurship, 1(6), 68-83.

Waweru, N. M., Munyoki, E., \& Uliana, E. (2008). The effects of behavioural factors in investment decision-making: A survey of institutional investors operating at the Nairobi Stock Exchange. International Journal of Business and Emerging Markets, 1(1), 24-41. https://doi.org/10.1504/IJBEM.2008.019243

Notes

Note 1. We did not show the Table for the Chronbach's Alpha results for each of the variables used for the study, and is available upon request.

\section{Copyrights}

Copyright for this article is retained by the author(s), with first publication rights granted to the journal.

This is an open-access article distributed under the terms and conditions of the Creative Commons Attribution license (http://creativecommons.org/licenses/by/4.0/). 